\title{
MULTIPROFESSZIONÁLIS REHABILITÁCIÓS TEAM KOMMUNIKÁCIÓJÁNAK VIZSGÁLATI LEHETŐSÉGEI
}

\author{
Szerző: \\ Angeli Csenge \\ SZTE Gyermekgyógyászati Klinka
}

Szerző e-mail címe: angelicsenge@gmail.com

\author{
Lektorok: \\ Feketéné Dr. Szabó Éva \\ Semmelweis Egyetem \\ Dr. Túri Ibolya \\ Semmelweis Egyetem \\ ...és további két anonim lektor
}

\begin{abstract}
Absztrakt
A magas rehabilitációs költségek csökkentése érdekében nagy jelentőségűek a rehabilitációs team hatékonyságára fókuszáló kutatások, így a kommunikációs vizsgálatok. Jelen tanulmány célja, hogy összegezze azokat a módszereket, melyekkel e kommunikációs mérések elvégezhetőek, kijelölve az utat következő, empirikus kutatásoknak. A team kommunikációjának mérését leggyakrabban a team-megbeszélés alkalmával vizsgálják, ezen felül azonban számos lehetőség áll rendelkezésünkre. A kép- és hangrögzítés nehézségeit más módszerekkel kombinálva kiküszöbölhetjük, illetve csökkenthetjük. Ez a tanulmány a potenciális vizsgálati helyzeteket és a gyakrabban alkalmazott módszereket összegzi.
\end{abstract}

Kulcsszavak: rehabilitáció, kommunikáció, team-kommunikáció

Diszciplina: orvostudomány

\section{Abstract}

MEASURMENT POSSIBILITIES

OF MULTIPROFESSIONAL REHABILITATION TEAM COMMUNICATION

In order to reduce high rehabilitation costs, research focusing on the effectiveness of the rehabilitation team, such as communication studies, is very important. The aime of the present study is to summarize the methods by which these communication measurements can be performed, marking the way for later empirical researches. Measuring team communication is most often examined during a team meeting, but in addition, we have number of options. The difficulties of image and sound recording 
can be eliminated or reduced when combined with oder methods. This study summarizes potential examination situations and commonly used methods.

Keywords: rehabilitation, communication, team communication

Discipline: Medicine

Angeli Csenge (2020): Multiprofesszionális rehabilitációs team kommunikációjának vizsgálati lehetőségei. OxIPO - interdiszciplináris tudományos folyóirat, 2020/3, 75-85. doi: 10.35405/OXIPO.2020.3.75

Az orvosi rehabilitáció költségei világszerte rendkívül magasak úgy gyermek-, mint a felnőtt kórképekben. Jó példázza ezt a rehabilitációs ellátást igénylő kórképek közül kiemelkedő Cerebralis Paresis (CP), melynek prevalenciája 2-4/1000 gyermek a 3-10 éves korosztályban (Cans, 2000) valamint a Stroke, melynek incidenciája 45-50 ezer fő/év, prevalenciája 180-200 ezer (Szende, Oppe és Devlin, 2006) és a leggyakoribb tartós rokkantágához vezető állapot. Az előbbi esetén 2019-es felmérés alapján Magyarországon egy gyermek költsége 18 éves koráig 73 millió HUF (251 $724 €$ ), valamint a GDP 0,525\%-át, a teljes egészségügyi és szociális költségvetés 0,88\%-át és a közvetlen orvosi költségek 1,83\%-át költötték a CPs családokra. (Fejes, Varga és Hollódy, 2019) A stroke évi 38 milliárd euróval az Európai Unió (EU) teljes egészségügyi kiadásainak 2-3\%-át teszi ki (Allender, és tsai., 2008).

A rehabilitációs ellátás eredményességének növelése lehet a kulcs a magas össz- gazdasági terhek csökkentésének, figyelembe véve - az említett kórképek példáján - az elhúzódó rehabilitációs szakasz, valamint a rehabilitáció sikerességtől függő posztrehabilitációs szakasz költségeit. Az ellátás rendelkezésére álló erőforrásainak optimalizálásával nem csupán az akut rehabilitációs szakaszban csökkenthetőek a költségek, de a várhatóan jobb funkcionális kimenetnek köszönhetően a hoszszútávú társadalmi és egyéni terhek is redukálhatóak. Az egyik legjelentősebb, e területen a rendelkezésünkre álló erőforrás a teambe rendezett humánerő. Jesus és Silva (2016) megállapítása szerint a rehabilitációban alkalmazott kommunikáció direkt és indirekt úton is befolyásolja a rehabilitáció eredményességét. Ennek fényében érdemes a rehabilitációs team kommunikációjával, mint a rehabilitáció egyik jelentősen befolyásoló tényezőjével foglalkoznunk, annak hatékonyságát, javíthatóságát az egyes teamekre vonatkoztatva megállapítanunk, hogy e mérések segítségünkre legyenek az általánosan le- 
vonható következtetések és ajánlások megfogalmazásában. A team struktúra feltérképezésével, a kommunikációs hibák feltárásával és javításával, a team tagjai közti konfliktusok felszínre emelésével, az egyéni kommunikációs hibák feltárásával lehetőség nyílik a dolgozók képességeinek adekvát fejlesztésére, a megfelelő munkahelyi légkör kialakítására és a hatékonyság fokozására. A szakmák közti esetleges ellentét, vagy a szakma alacsonyabb presztízséből fakadó feszültség is felszínre kerülhet többek közt a tartalmi elemzés hatására. A humánerő bevonásával (a vizsgálati eredmények ismertetése, megoldási módok, javaslatok biztosítása) a dolgozó kompetensebbé válhat a felmerülő problémák megoldásában.

Jelen tanulmány célja, hogy összegezze azokat a módszereket, melyekkel a multiprofesszionális rehabilitációs team kommunikációja mérhető, annak érdekében, hogy megalapozza a később erre építhető kutatásokat.

\section{A REHABILITÁCIÓS TEAM SAJÁTOSSÁGAI}

Az orvosi rehabilitáció sajátos tulajdonsága, hogy az egészségügyre jellemző hierarchikus rendszerbe ágyazva, a rehabilitációs ellátás igényeinek megfelelően, más egészségügyi ellátásra nem jellemző felépítésű, multiprofesszionális teammunkán alapul.

A team összetétele kórképenként, illetve betegenként is változhat. (Kullmann,
2010) A team tagjai eltérő szaktudással és rálátással, más-más háttérrel rendelkeznek. Kullmann és Vekerdy (2006) alapján a legfontosabb team tagok a következők: rehabilitációs szakorvos, ápoló, szakápoló, fizioterapeuta (gyógytornász), szakgyógytornász, kineziológus, konduktor, foglalkoztató terapeuta, klinikai szakpszichológus, neuro-pszichológus, logopédus (beszédterapeuta), szomato-pedagógus, testnevelő tanár, gyógytestnevelő, fizikoterápiás asszisztens, gyógymasszőr, dietetikus, ortopéd műszerész.

A teamben megtalálható egyes szakemberek képzése jellemzően más felépítésû munkakörnyezetben végzett tevékenységre készítik fel hallgatóit. Így például az orvosok (a rehabilitációs szakorvos képzést nem számítva) és ápolók az egészségügyi team munkára, az ott megszokott hierarchikus rendszerre kapnak felkészítést, (Kullmann, 2010) a gyógypedagógusok, konduktorok jellemzően inkább pedagógus munkaközösségekben, tantestületekben, az oktatási szféra jellemzőire készülnek (Kullmann, 2015). A szakmák eltérő szemlélete és terminológiája tovább bonyolítja a munka közös irányának kialakítását. A szakemberek képzésében kevéssé, vagy egyáltalán nem kap szerepet a teammunkára felkészítés (Kullmann, 2015).

A problémák áthidalását elősegítheti a közös nyelv kialakítása, melyre jó példa a funkcióképesség, fogyatékosság és egészség nemzetközi osztályozása (FNO) használatának bevezetése (Allan és tsai, 
2006; Tempest és McIntyre, 2006). A team felépítésétől függően a team tagjai a más szakmák által használt terminológiák ismeretére és megértésére való törekvéssel, akár annak használatával tudják elősegíteni a közös munkát.

A rehabilitációban a teammunkának alapvetően három modelljét különítjük el: a multidiszciplináris, az interdiszciplináris és transzdiszciplináris modellt. A különböző team működési formákban a team tagjai közti viszonyban jelentős eltéréseket találunk, melyek a kommunikációs mintázatokban is jelentkeznek.

Multidiszciplináris team esetén a team minden tagja önállóan, egyénileg végzi munkáját, a team vezetőjének felel, vele áll közvetlen és közeli kapcsolatban (Norrefalk, 2003). Interakció így leggyakrabban a team egy tagja és a team vezetője közt, illetve a team egy tagja és a páciens, vagy hozzátartozója közt jön létre.

Interdiszciplináris teamekre jellemző, hogy bár a tagjai szintén egyénileg végzik munkájukat, azonban kölcsönös konzultációk alkalmával zajlik kommunikáció a team tagjai közt. A célok és a rehabilitációs terv a pácienssel és családjával is egyeztetésre kerülnek. Lehetőség nyílik ilyen módon közös vélemény és kezelési menet kialakítására, melyet a szakemberek saját tevékenységükbe integrálva hajtanak végre (Körner, 2010). A kommunikáció a team minden tagja közt zajlik, gyakoriságában és irányában azonban találhatunk aszimmetriákat.
Az oktatási modellből kifejlődő transzdiszciplináris team modell ismérve a kommunikációt meghaladó együttmúködés. A közösen végzett vizsgálatok és a tapasztalatok közös kielemzésén túl a pácienssel és családjával is még szorosabb együttmúködés létesíthető. $\mathrm{E}$ teamen belüli kooperáció sajátosságai a szerepkiterjesztés, szerepszélesedés, szerepátadás, szerepmegosztás, valamint a szerepsegítés (Lyon és Lyon, 1980; Woodruff és McGonigel, 1988; King és tsai, 2009). Ez a modell az, melyben leginkább hangsúlyos a rendszeres kommunikáció és az információcsere (Kullmann, 2015).

A team, annak múködési formájától függetlenül, folyamatos változáson esik át. Új team tag bekerülésével vagy távozásával a korábbi, megszokott munkarend felborul, az új helyzethez való alkalmazkodást követően pedig új rend alakul ki. Ezt a folyamatot team-dinamikának nevezzük. Főbb állomásai a következők: az ismerkedés szakasza (forming), a feszültség szakasza (storming), a csoportnormák kialakításának szakasza (norming), az érdemi munka szakasza (performing) és a szétválás szakasza (adjourning) - (Tuckman, 1965; Tuckman és Jensen, 1977).

A rehabilitációs munka szervezésének sajátossága az egészségügyi rendszerre jellemző munkaközösséggel szemben (bár az orvosi gyakorlat más területein is találhatunk elmozdulást a páciens partneri viszonyba helyezése felé), hogy a páciens és családja a team aktív tagja. 
A fent felsorolt modellek mindegyikére igaz ez, csupán a részvételi arányban találunk eltérést.

A team kommunikációjának mérésekor érdemes figyelembe venni a teamdinamikát, előzetesen felmérni, hogy a vizsgált team nyugvó, vagy változó fázisban van-e, illetve ha ez utóbbi eset áll fenn, akkor mely szakaszban tart a változás, hogy a team-dinamika fázisok kommunikációt befolyásoló hatását figyelembe véve tudjuk az eredményeket értékelni.

\section{A MÉRÉS TÁRGYA}

A kommunikáció, mint esetünkben vizsgálandó jelenség a team szintjén jelentkező folyamat. Minden kommunikációs folyamatban a team legalább két tagja vesz részt. Két résztvevő közti interakció gyakran fordul elő minden rehabilitációs teamben, leggyakrabban mikor a team egyik szakértő tagja a pácienssel lép kapcsolatba és fordítva. Ezen felül a team szervezett találkozásain kívül - melyet a későbbiekben tárgyalunk - a tagok spontán, szabadon szerveződő kisebb csoportjai is kommunikálnak egymással, vegyes team összetételben. A továbbiakban a team szervezett találkozásainak mérési lehetőségeit vesszük számba, a spontán szereveződő team-interakciós vizsgálatokat nem tárgyaljuk, figyelembe véve annak mérési nehézségeit. Ugyanakkor e helyzetek team hatékonyságra gyakorolt vélhető hatása, illetve a hatékonyság indikátoraként betöltött szerepének lehetősége okán e terület feldolgozását egy későbbi tanulmányban vesszük górcső alá.

A szervezett team találkozások esetén mérhetők az egyén, illetve a vizsgált csoport (team egyes tagjai vagy a teljes team) interakciós megnyilvánulásai. Az egyén szempontjából (eltekintve az intraperszonális kommunikáció vizsgálatától), a verbális és nonverbális megnyilvánulások rögzítése kézenfekvő. A teamet alkotó szakmákra külön-külön vonatkozó szakirodalomban (orvos-beteg kommunikáció, pedagógus kommunikációja, stb.) a kommunikáció formai és tartalmi, valamint mennyiségi vizsgálata jellemző. Ilyen például a beszéd és annak stíluselemei, az érthetőség, egyértelműség, a megértés, a non-verbális megnyilvánulások, illetve azok viszonya a verbális kommunikációhoz. Az orvos-beteg találkozás vizsgálatainak megállapításai rendkívül jelentősek lehetnek, tekintve a teamen belüli szakember-páciens gyakori - és a kezelések, foglalkozások alkalmával hosszú ideig tartó- találkozását. Az egyéni szintű adatok alapján a team tagjának teamben betöltött szerepéhez viszonyított kommunikációs tevékenysége (például a team vezetőjének verbális és nonverbális megnyilvánulásai mennyiben tükrözik pozícióját) is felszínre kerülhet. Ennek jelentősége abban állhat, hogy a teljes team vizsgálatakor kapott egyes eredmények, ha teljes magyarázatot nem is kapnak, de a team tagjai közti viszony egyik dimenzióját alkotva a team hangulatának, szorongási szintjének egyik magyarázó oka lehet, természetesen a to- 
vábbi körülmények gondos vizsgálata és figyelembevétele mellett. További haszna lehet a humánerő fejlesztés szempontjából, hogy a teamben betöltött szerepre vonatkoztatva kapott eredmények által fény derülhet a dolgozó bizonytalanságára, egyes hibáira, melyek ily módon javíthatóvá válhat, a munkaerő adekvát irányú továbbképzése és fejlesztése megvalósulhat, ezáltal javítva a team hatékonyságát.

A több résztvevős kommunikációs helyzetek vizsgálatában az egyéni szintű megfigyelésből nyert adatok és eredmények (nonverbális megnyilvánulások, a verbális és nonverbális kommunikáció viszonya, stb.) megfelelő kontextusba kerülnek. A team egyes csoportjainak, illetve a teljes team vizsgálatát több szempont alapján is végezhetjük. Lehetőségünk nyilik a tagok interakcióinak irányát és mennyiségét mérve a tagok aktivitását meghatározni, valamint következtethetünk a teamben képviseltetett szakmák preferációjára és megállapíthatjuk a vizsgált csoportban alkalmazott team modellt is. Hámornik (2013) az általa vizsgált rehabilitációs teamben például az orvos központi szerepén túl rámutat a gyógytornász szakmát és az ápoló szakmát képviselők közti kommunikáció alacsony mértékére a gyógytornász-orvos, illetve az ápoló-orvos kommunikáció mennyiségéhez képest.

\section{A TEAM-INTERAKCIÓK HELYE}

A következőkben áttekintjük a team találkozásokat, melyek a mérés helyeként szolgálhatnak. A tervezett interakciók a következő fontosabb tevékenységekhez köthetőek a rehabilitációs gyakorlatban:

- Team-megbeszélés,

- „Kis” team-megbeszélés,

- Vizitek, heti nagyvizit,

- Több team tag részvételével végzett betegvizsgálat,

- Egyéni megbeszélések, állapotfelmérés, terápiák,

- Dokumentáció elemzése.

Team-megbeszélés során bár a team teljes létszámmal nem lehet jelen az ügyeletek és az eltérő múszakok miatt (például ápolók esetén), ugyanakkor a munkában résztvevő minden szakma képviselteti magát. Jellemzően heti egy alkalommal vagy kéthetente szervezett megbeszélés, a páciens részvétele nélkül zajlik, s a rehabilitációs osztályon ellátott minden beteg megbeszélésre kerül (Bokhour, 2006). Ezen alkalommal áttekintésre kerül a betegek állapota, igényei illetve itt történik a közös célmeghatározás is (Bokhour, 2006). „Kis” team-megbeszélésen a team minden tagja nem vesz rész, csupán a beteg és hozzátartozója valamint a páciens felmerülő problémáival kapcsolatban kompetens, a beteggel közvetlenül foglalkozó team tagok. Az ilyen alacsonyabb számú személlyel történő megbeszélés egyik példája a célegyeztető megbeszélés. Az Országos Orvosi Rehabilitációs Intézetben saját célegyeztető megbeszélés protokollját dolgozták ki, melynek egyik rendeltetése a páciens elvárásainak, saját céljainak megismerését követően a rehabilitációs célok közös kialakítása, mellyel 
lehetőség nyílik a páciens esetlegesen túlzó, irreális elvárásainak a megvalósítható irányba terelése, a későbbi viták és ellentétek megelőzése (Szél és tsai, 2015). A protokoll használata során logisztikai nehézségeket okozott ugyan munkaidőben a különböző beosztású team tagok és a hozzátartozók egyidejü jelenléte, ugyanakkor többek közt a team tagjai közi kommunikáció könnyítését kedvezően befolyásolta, illetve a hozzátartozók is pozitív visszajelzést adtak. Bár alacsonyabb számú személy interakcióinak felmérésre ad lehetőséget ez az alkalom, mégis nagy jelentőséggel bírhat, mivel mind a beteg körüli kezelő személyzet, mind a páciens és közvetlen támogató hálózata jelen van, így olyan folyamatok rögzítésére is lehetőség nyílik, melyre más alkalommal nem lenne lehetőség.

Bár a heti Nagyvizitek alkalmával is jelen van a páciens, a vizsgáló team mozgásban van, szisztematikusan halad végig az osztály kórtermein betegtől-beteghez tartva. Ezeken az alkalmakon a kórteremben tartózkodó összes beteg hallja az elhangzottakat, továbbá a jelen lévő szakemberek közt nem csupán a beteggel közvetlenül foglalkozó team tagok vesznek rész, hanem jellemzően a teammegbeszélésen jelen lévő teljes team. Emiatt a nagyvizitek alkalmával kevésbé van alkalma a betegnek is és a személyzetnek is a bizalmas kérdések megvitatásásra.

A fenti alkalmak lehetőséget biztosítanak a team-interakciók, a páciens és a szakember-team interakcióinak vizsgálatára. Gyakori kommunikációs helyzet a rehabilitációs ellátás során a beteg vizsgálata és kezelése, melyen egy, vagy az előbbin akár több team tag is részt vehet. Ezen találkozások adhatnak lehetőséget a szakember-páciens interakciók megfigyelésére és vizsgálatára.

A dokumentáció folyamatos vezetése mellett a team-megbeszélés alkalmával is előkerül, ahol a friss beteg-adatokat, célokat rögzítik. Segítségével térben és időben eltérő helyen van lehetőség az információcserére, így annak elemzésével érdemes kiegészíteni a team kommunikációjának vizsgálatát.

A fentiek vizsgálati lehetőségeit és korlátait a következőkben tárgyalom.

\section{A MÉRÉS \\ MÓDSZEREI, ESZKÖZEI}

Az interakciók vizsgálatakor a megfigyelés végzése elengedhetetlen. Ezt természetesen tervszerűen végezzük, így a terepmunkát megelőzően választjuk ki azokat a technikákat, melyeket alkalmazni szándékozunk. A hang és képanyag rögzítése rendkívüli előnyökkel jár: az anyag bármikor visszajátszható, újra elemezhető, az interakció lassításával olyan elemeket is képesek vagyunk elemezni, melyre valós időben nem nyílna lehetőségünk. A nonverbális kommunikáció vizsgálatához kiemelten fontos videó készítés. Kézenfekvő hasznuk mellett ugyanakkor alkalmazásuk több akadályba is ütközik. A képi-és hanganyag rögzítésére szolgáló kamera és 
a csak hanganyagot rögzítő magnó erős zavaró hatásával kell számolnunk. A team tagjai a megszokottól eltérő viselkedést mutathatnak, az interakciók mennyiségi és minőségi mutatói torzulhatnak. A hatás korrigálható szoktatási idővel, ám ez rendkívül időigényes. A kamerahasználat további problematikája annak korlátozott látószöge. A team-megbeszélés során a team tagjai jellemzően asztal mellett, ovális vagy kör alakzatban helyezkednek el, ami miatt több kamera használata válhat szükségessé (Hutchins, 1995). Így természetesen a kamera zavaró hatása is erőteljesebben érvényesülhet. A team-megbeszélés, a „kis” team-megbeszélés helyhez kötötten zajlik, a kommunikáló felek helyüket az interakciósor végéig nem változtatják, így viszonylagosan egyszerű a felvevőegységek beállítása. Vizitek alkalmával viszont a vizsgáló team betegtől betegig halad, a team tagjai egymáshoz képesti helyzetüket és helyüket is változtatják. Ebben a helyzetben a képi anyag, az öszszes résztvevő nonverbális jelzéseinek rögzítése gyakorlatilag lehetetlenné válik. A hangfelvétel készítése is nehézkes: a felvevő eszközt megfelelő távolságon belül szükséges tartani a feldolgozható minőségű hanganyag rögzítése érdekében. A mobilitás problémája kapcsán alternatívát nyújthat például a LENA (Language Environment Analysis/nyelvi környezet elemzés), mely rendszer egy hordozható felvevőegység tárolására alkalmas zsebbel rendelkezik, melyet a vizsgált személyre rögzítve, annak minden verbális reakciója rögzíthetővé teszi (Oller és tsai., 2010). Minden osztályos páciensre alkalmazva rendkívül költségessé válna a vizsgálat, így a teljes vizit hanganyagának rögzítése nem valósítható meg, ugyanakkor egy-egy beteg vizsgálatára alkalmas lehet a rendszer. A terápiák és vizsgálatok egy-egy teremben vagy szobában zajlanak, kevesebb a mozgás, mint a vizitek alkalmával, azonban tapasztalhatjuk itt is a jelenlévők helyés helyzetváltoztatásából, valamint a kamera látószögnek korlátozottságából fakadó problémákat. Ebben az esetben is több eszköz használata válna szükségessé, melyek zavaró hatásán túl az eredmények elemzését bonyolultabbá teszi. A hang és képanyag rögzítése, tárolása és felhasználása - a többi módszer esetében is vezérfonálként és alapkövetelményként betartott kutatásetikai követelményeken túl további engedélyezésekre is szükséges gondolnunk a hatályos jogszabályok értelmében (GDPR).

Bármely interakciós helyzetben a hanganyag felvételhez kiegészítő eljárás alkalmazása szükséges. Ennek egyik lehetősége a jegyzőkönyv, vagy napló készítése, párhuzamosan a hangrögzítéssel. A napló kevésbé kötött rögzítési forma, így alkalom nyilik új, nem várt jelenségek rögzítésére is, melyek segítségével a vizsgálat új aspektusai tűnhetnek fel, megalapozva újabb hipotézisek, elméletek születését és további vizsgálatok facilitálását (Falus, 2004). A jegyzőkönyv sokkal inkább objektív, a megfigyelő személyétől kevésbé függő megfigyelési forma (Falus, 2004). 
Teljes jegyzőkönyvnek minősül maga a magnó és a videokamera is, ugyanakkor a hanganyag írott jegyzőkönyvvel történő kiegészítése segítséget nyújthat annak pontosítására. Hámornik (2013) online regisztrációs módszert dolgozott ki, melylyel valós időben rögzíthető volt a közlő és a címzett. A hangfelvétel ilyen jellegű kiegészítése lehetővé teszi az adatok pontosítását és gyorsabb feldolgozhatóságát, biztosítja, hogy a hanganyag elhangzott egységeit a megfelelő szakemberhez tudjuk társítani, mely csupán a team tag hangja alapján bizonytalan volna.

A team hatékonyságának felmérése, megtartása vagy fejlesztése érdekében végzett team-kommunikáció vizsgálatot további módszerekkel egészíthetjük ki. A kikérdezés módszerével közvetlenül a team tagjaitól nyerhetünk információt ismereteikre, véleményükre és attitűdjükre (Nádasi, 2004). A személyes kapcsolatrendszer - mint a formális kapcsolatrendszer befolyásoló tényezője - szociometriai kérdőív segítségével mérhető fel.

\section{KONKLÚZIÓ}

A team kommunikációjának mérését vizsgáló módszer kiválasztásakor figyelembe szükséges vennünk a rehabilitációs team sajátosságait. Az orvosi rehabilitációban a munkaközösség mindig multiprofesszionális szerveződésű, s minden esetben tagja a páciens és annak családja is. Eltérő team modelleket találhatunk, melyek megállapításához az interakciós vizsgálatok segítséget nyújtatnak. A vizsgálati eredményeink értékelésekor e modelleket és a team dinamikájának állomásit is szükséges figyelembe vennünk. Vizsgálatunk célja lehet a kommunikációs folyamat sajátosságainak rögzítése, illetve eredményességének meghatározása. Szükséges e vizsgálati célhoz társítanunk a vizsgálati, interakciós-helyzetet. A gondosan megválasztott mérési helyzet mellett a megfigyelés eszközeinek meg kell felelniük a könynyú és pontos használhatóságnak. Az etikai és mérési nehézségek a vizsgálati helyzettôl függetlenül jelen vannak, az utóbbi enyhítésére a módszerek kombinációja szükséges.

\section{IRODALOM}

Allan, C. M., Campbell, W. N., Guptill, C. A., Stephenson, F. F., \& Campbell, K. E. (2006). A conceptual model for interprofessional education: The International Classification of Functioning Disability and Health (ICF). Journal of Interprofessional Care, 20, 235-245 doi: $\underline{10.1080 / 13561820600718139}$

Allender, S., Scarborough, P., Peto, V., Rayner, M., Leal, J., LuengoFernandez, R., és mtsai. (2008). European cardiovascular disease statistics 2008 edition. European Heart Network.

Bokhour, B. G. (2006). Communication in interdisciplinary team meetings: what are we talking about? Journal of Interprofessional Care, 20(4), 349-363. doi: $\underline{10.1080 / 13561820600727205}$ 
Cans, C. (2000). Surveiilance of cerebral palsy in Europe: a collaboration of cerebral palsy surveys and registers. Developmental Medicinie \& Child Neurology, 42, 816-24. doi: 10.1111/j.1469-8749.2000.tb00695.x

Falus I. (2004). A megfigyelés. In I. Falus I. (szerk.): Bevezetés a pedagógiai kutatás módszereibe. Budapest: Műszaki Könyvkiadó. 99-118.

Fejes, M., Varga, B. és Hollódy, K. (2019). A cerebralis paresis epidemiológiája, költségei és közgazdasági hatásai. Ideggyógyászati Szemle, 72, 3-4. doi: $\underline{10.18071 / \text { isz. } 72.0115}$

Hámornik, B. P. (2013). Team-tudás, interakció és kommunikáció vizsgálataTudásmegosztás az orvosi rehabilitációs teamben. Doktori Disszertáció. ELTE.

Hutchins, E. (1995). Cognition in the Wild. The MIT Press. doi: 10.1098/rsbl.2011.0352

Jesus, T.S., \& Silva, I.L. (2016). Toward an evidence-based patient-provider communication in rehabilitation: linking communication elements to better rehabilitation outcomes. Clinical Rehabilitation, 30, 315-328. doi: $\underline{10.1177 / 0269215515585133}$

King, G., Strachan, D., Tucker, M., Duwyn, B., Desserud, S., \& Shillington, M. (2009). The Application of a Transdisciplinary Model for Early Intervention Services. Infants \& Young, 22, 211-223. doi: 10.1097/IYC.0b013e3181abe1c3
Körner, M. (2010). Interprofessional teamwork in medical rehabilitation: a comparison of multidisciplinary and interdisciplinary team approach. Clinical rehabilitation, 24(8), 745-755. doi: $10.1177 / 0269215510367538$

Kullmann L. (2010). A rehabilitációs orvoslás elmélete. In Vekerdy-Nagy Z. (szerk.): Rehabilitációs orvoslás. Budapest: Medicina. 23-30.

Kullmann L. (2015). A teammunkára felkészítés lehetőségei a gyógypedagógusképzésben. Gyógypedagógiai Szemle, 43(3), 178-192.

Kullmann L., \& Vekerdy Z. (2006). A képzés jelentősége: Szakemberellátottság a rehabilitációban. Kórház, 12(6), 89-93.

Lyon, S., \& Lyon, G. (1980). Team functioning and staff developmnet: A role release approach to providing integrated education services for severely hadicapped students. The Journal of Association for the Severly Handicapped, 5, 250-263. doi: $\underline{10.1177 / 154079698000500304}$

Nádasi M. (2004). A kikérdezés. In Falus I. (szerk.): Bevezetés a pedagógiai kutatásmódszereibe. Műszaki Könyvkiadó, Budapest. 141-159.

Norrefalk, J.R. (2003). How do we define multidisciplinary rehabilitation? Journal of Rehabilitation Medicine, 35(2), 100-101. doi: $\underline{10.1080 / 16501970306118}$

Oller, D. K., Niyogi, P., Gray, S., Richards, J. A., Gilkerson, J., Xu, D., és mtsai. (2010). Automated vocal 
analysis of naturalistic recordings from children with autism, language delay, and typical development. Proceedings of the National Academy of Sciences of the United States of America, 107(30), 1335413359. doi: $10.1073 /$ pnas.1003882107

Szél, I., Tóth, A., Kozma, G., Vámos, T., Schneider, H. és Bíró, T. (2015). Célegyeztető megbeszélés: Magyarországon újdonságnak számító, tervezett, teljes körű kommunikációs módszer a rehabilitációs program részeként. Rehabiliáció, 25(3), 112.

Szende, A., Oppe, M., \& Devlin, N. (2006). EQ-5D Value Sets: Inventory, Comparative Review and User Guide. Springer .

Tempest, S., \& McIntyre, A. (2006). Using the ICF to clarify team roles and demonstrate clinical reasoning in stroke rehabilitation. Disability and Rehabilitation, 28, 663-667.

Tuckman, B. W. (1965). Developmental Sequence in Small Groups. Psychological Bulletin, 63(6), 384-399. doi: $\underline{10.1080 / 09638280500276992}$

Tuckman, B. W., \& Jensen, M. C. (1977). Stages of small group development revisited. Group and Organization, 2(4), 419-427. doi:

$\underline{10.1177 / 105960117700200404}$

Woodruff, G., \& McGonigel, M. J. (1988). Early Intervention Team Approaches: The Transdisciplinary Model. In Jordan, June, Ed. and Others (Eds.): Early childhood special education: Birth to three. Washington, D.C.: Office of Educational Research and Improvement. Reston, VA: Council for Exceptional Children. 6485. 